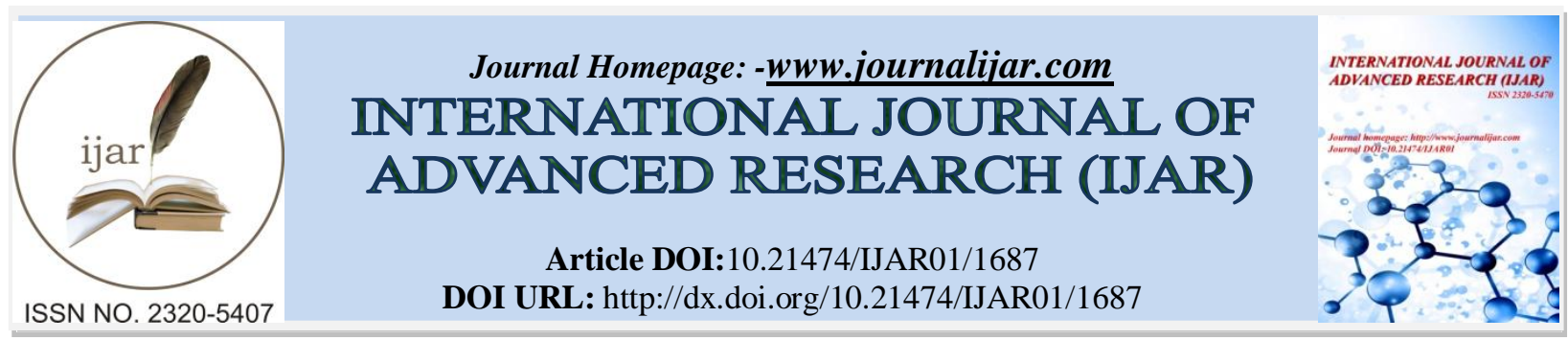

RESEARCH ARTICLE

\title{
ALTERATIONS IN FISH GILL PROFILE AFTER SUB LETHAL LEAD EXPOSURE: A SPECTROSCOPIC STUDY.
}

\author{
V. R. Chavan. \\ Department of Zoology, Balwant College, Vita - 415 311. (MH), India.
}

Manuscript Info
Manuscript History
Received: 12 July 2016
Final Accepted: 13 August 2016
Published: September 2016
Key words:-
Cirrhinus mrigala, gill, lead exposure,
field emission scanning electron
microscopy

\section{Abstract}

Contamination of fresh water ecosystems with a number of heavy metals affects the ecosystems integrity and induces serious ecological consequences. Serious damage to aquaculture species such as fish is due to purely toxic, widely used heavy metals like lead and mercury. The present study has been undertaken to explore the toxic effects of lead on gill of fish Cirrhinus mrigala and to detect the spectral and surface morphological changes in it. The biochemical changes after chronic lead exposure are studied by currently used methods of monitoring animal tissue and their components like Fourier transform infrared spectroscopy (FTIR), energy dispersive X-ray spectroscopy (EDX) and Optical absorbance. The surface morphology of gill is studied by field emission scanning electron microscopy (FE-SEM). The present study provides a better understanding of metal toxicity on the alterations at cellular level after chronic exposure to lead.

Copy Right, IJAR, 2016,. All rights reserved

\section{Introduction:-}

Heavy metal pollution is a major burning issue in developing countries like India. Rapid urbanization, industrial development, consumerist life style and anthropogenic sources have increased the release of heavy metals in our resources during last few decades. Heavy metals dissolved in water are readily available to aquatic organisms and cause serious effects on their health. Metals in the polluted resources enter into aquatic animals like fish through food chain. Heavy metals can be bio accumulated and biomagnified via food chain and finally consumed by human resulting in health hazards (Abdel-Baki et al., 2011). Fish are often used as indicators' of heavy metals as they occupy high trophic levels and are important as food (Agah et al., 2010). By decreasing the reproductive potential of fish, metals may cause a long term decline in fish population which eventually results in extinction of species (Burger and Gochfeld, 2005). It is well known that ecological consequences induced by heavy metals disturb the biogenesis resulting in loss of aquatic ecosystems integrity (Vosylienè and Jankaite, 2006). Gross pollution of aquatic bodies by heavy metals makes the water non-potable and brings heavy fish mortality. In recent years bulk fish mortality after release of industrial effluents is a common incidence in many parts of India. Pollutants affect the behavior, endocrine secretions, metabolism and reproduction of aquatic organisms (Rurangwa et al., 1998). Low levels of pollution may have no apparent impact on the fish itself, however it may decrease the fecundity leading to a long-term decline and eventual extinction of this important natural resource (Burger and Gochfeld, 2005). Effects of heavy metals on fish are multidirectional and manifested by numerous changes in physiological and chemical process of the body system (David and Kartheek, 2015). A thorough understanding about the toxic effects of metals is hence necessary. 
Lead is a heavy metal not required by any living organism hence can be described as purely toxic. A considerable lead is disposed of in the aquatic system every year. Recent reports indicated that lead can affect the nervous, digestive, reproductive, circulatory and immune, system in the animals (Al-Balawi et al., 2013). Lead displaces biologically important metals such as calcium, zinc and magnesium interfering with a variety of body's chemical reactions.

Gills are highly dynamic organs exposed directly to contaminated waters and are target organs of immediate effects of chemicals (Oliveira et al., 2008). By crossing biological membranes heavy metals tend to accumulate in metabolically active tissues like gills. Disturbances in vital processes and changes the biochemistry due to metal accumulation ultimately reduces food quality of fish (Messner, 2016). Gills are the first organ to which the pollutant comes into contact. The gills are hence more vulnerable to damage than any other tissue. Gill is an organ associated with vital functions like gas exchange and waste removal. Gill histology hence serves as a tool for studying environmental pollution (Chavan and Muley, 2014).

FTIR spectroscopy serves as an important and popular tool to get the quantitative profile of biochemical composition of biological sample with little sample and short preparation. FE-SEM provides surface morphological details.Compositional analysis of carbon and oxygen is studied by EDS. UV visible spectrophotometer is used to check the optical response of biological sample and photoluminescence can be studied by spectrofluorometer. The present study was undertaken to explore the effect of lead exposure on gill of an edible fresh water fish Cirrhinus mrigala.

\section{Materials and Methods:- \\ Biological material:-}

The live fresh water teleostCirrhinus mrigala of average length $18-20 \mathrm{~cm}$ and average body weight $70-75 \mathrm{~g}$ were collected from a reservoir at Kalambe near Kolhapur, M. S. India. Animals were rinsed with water containing little amount of $\mathrm{KMnO} 4$ to disinfect them. Animals were then transferred to glass aquarium with continuously aerated tap water for acclimatization. After two weeks acclimatization healthy fishes were identified by general appearance and selected for experimental work. The water was checked for selected Physico chemical parameters (pH 7.2-7.4, Temperature $20-23^{\circ} \mathrm{C}$, Dissolved oxygen $6.8 \mathrm{mg} / \mathrm{l}$ ). Fish were fed ad libitum with groundnut oil cake during acclimatization and exposure to toxicant.

\section{Exposure:-}

Chemicals-Analytical grade lead acetate (BDH) was used without further purification.

The heavy metal lead was used in the form of lead acetate for the present study. The LC50 values of lead were determined by static bioassay of 96 hours and the sub lethal concentrations of toxicants were selected for the chronic toxicity tests of long-term exposures. (See supplementary information). A prolonged (chronic) period of 30 days was selected for the present study. The sub lethal concentrations of toxicants i.e. lead acetate selected for the chronic toxicity study (30 days) were $1 / 20^{\text {th }}$ and $1 / 10^{\text {th }}$ concentrations of LC50 values. These values for lead acetate were 14.1 and 28.2ppm respectively.

The acclimated test animals in a group of 10 were exposed to these sub lethal concentration for a period of 30 days. The toxicity study was run in triplicates. A control set was run simultaneously. Fish were fed ad libitum during the study period. The toxicant was renewed completely by replacing fresh solution of same concentration. All bioassays were performed in triplicates for 30 days. The fish were sacrificed after 30 days and the desired tissue was pulled out. Sample preparation - The gill tissue was blotted and dried for $72 \mathrm{hrs}$ in oven at $60^{\circ} \mathrm{C}$.and then ground in mortar and pestle to obtain gill powder. Further spectroscopic analysis of the powder was done.

The vibrational analysis of gill of $C$. mrigala has been studied using the Perkin elmer, USA, Fourier transform infrared spectroscope (FTIR). Field emission scanning electron microscope (Mira 3, Tescan, chez republic), was used to study the ultra-structural details of fish gill. Energy dispersive spectroscopy has been studied using the Mira 3 Tescan an oxford instrument, United Kingdom. By using a UV-1800 Shimadzu, Japan absorption spectra were recorded at room temperature and near to normal incidence. Photoluminescence has been studied using the fluoromax-4, horiba instrument PVT, Japan. 


\section{Results and Discussion:-}

FTIR spectroscopic study:-

Fig. 1 shows the FTIR spectra for lead exposed C. mrigala gill in the spectral region $490-4000 \mathrm{~cm}^{-1}$. All the bands of after and before lead exposure are mentioned in Table.1. The bands at $3646 \mathrm{~cm}^{-1}$ and $3648 \mathrm{~cm}^{-1}$ for control and lead exposed at $14.1 \mathrm{ppm}$, respectively represent the $\mathrm{O}-\mathrm{H}$ stretching for alcohols and phenols functional group. The FTIR peak at 3378,3408 and $3329 \mathrm{~cm}^{-1}$ for control, lead exposed at $14.1 \mathrm{ppm}$ and lead exposed at $28.2 \mathrm{ppm}$, respectively belong to $\mathrm{O}-\mathrm{H}$ stretching or $\mathrm{H}$ bondfor alcohols and phenols. The peak at $2923 \mathrm{~cm}^{-1}$ for all samples represents the $\mathrm{C}-\mathrm{H}$ stretching for alkanes. Also this frequency belongs to lipids in the gill (Krafft et al., 2004). The peak at $1648 \mathrm{~cm}-1$ belongs to $-\mathrm{C}=\mathrm{C}-$ stretch for alkanes has been observed for control, lead exposed at $14.1 \mathrm{ppm}$ and $28.2 \mathrm{ppm}$ also. The peak at 1550, 1543 and 1526 for control, lead exposed at $14.1 \mathrm{ppm}$ and lead exposed at 28.2 ppm for N-O asymmetric stretch for the nitro compounds. The peak for control, lead exposed at $14.1 \mathrm{ppm}$ and lead exposed at $28.2 \mathrm{ppm}$ observed at 1339, 1332 and $1329 \mathrm{~cm}-1$, respectively for C-N stretch, C-O stretch for aromatic amines, alcohols, carboxylic acids, esters, ethers etc. The peak at $674 \mathrm{~cm}-1$ for control and $14.1 \mathrm{ppm}$ lead exposed samples as well as peak at $706 \mathrm{~cm}^{-1}$ for $28.2 \mathrm{ppm}$ lead exposed samples are indicating the $-\mathrm{C} \equiv \mathrm{C}-\mathrm{H}: \mathrm{C}-\mathrm{H}$ bonds for alkynes (Toyran et al., 2007)(Cakmak et al., 2006).

Table.1:-General band assignment of the FTIR spectra of control and lead exposed C. mrigala gill

\begin{tabular}{|l|l|l|l|l|l|}
\hline \multirow{2}{*}{$\begin{array}{l}\text { Sr. } \\
\text { No. }\end{array}$} & \multicolumn{3}{|c|}{ Frequency $\left(\mathbf{c m}^{-1}\right)$} & \multicolumn{1}{|c|}{ Bonds } & Functional group \\
\hline 1. & Control & $\mathbf{1 4 . 1 p p m}$ & $\mathbf{2 8 . 2 p p m}$ & & \\
\hline 2. & 3646 & 3648 & -- & O-H stretch, free hydroxyl & Alcohols, phenols \\
\hline 3. & 2923 & 3408 & 3329 & O-H stretch, H-bonded & Alcohols, Phenols \\
\hline 4. & 1648 & 1648 & 2923 & C-H stretch & Alkanes \\
\hline 5. & 1550 & 1543 & 1648 & - C=C- stretch & alkenes \\
\hline 6. & 1339 & 1332 & 1326 & N-O asymmetric stretch & Nitro compounds \\
& & & $\begin{array}{l}\text { C-N stretch } \\
\text { C-O stretch }\end{array}$ & $\begin{array}{l}\text { Aromatic amines } \\
\text { Alcohols, Carboxylic } \\
\text { acids, Esters, Ethers }\end{array}$ \\
\hline 7. & 674 & 674 & 706 & - C $=$ C-H:C-H bend & Alkynes \\
\hline
\end{tabular}

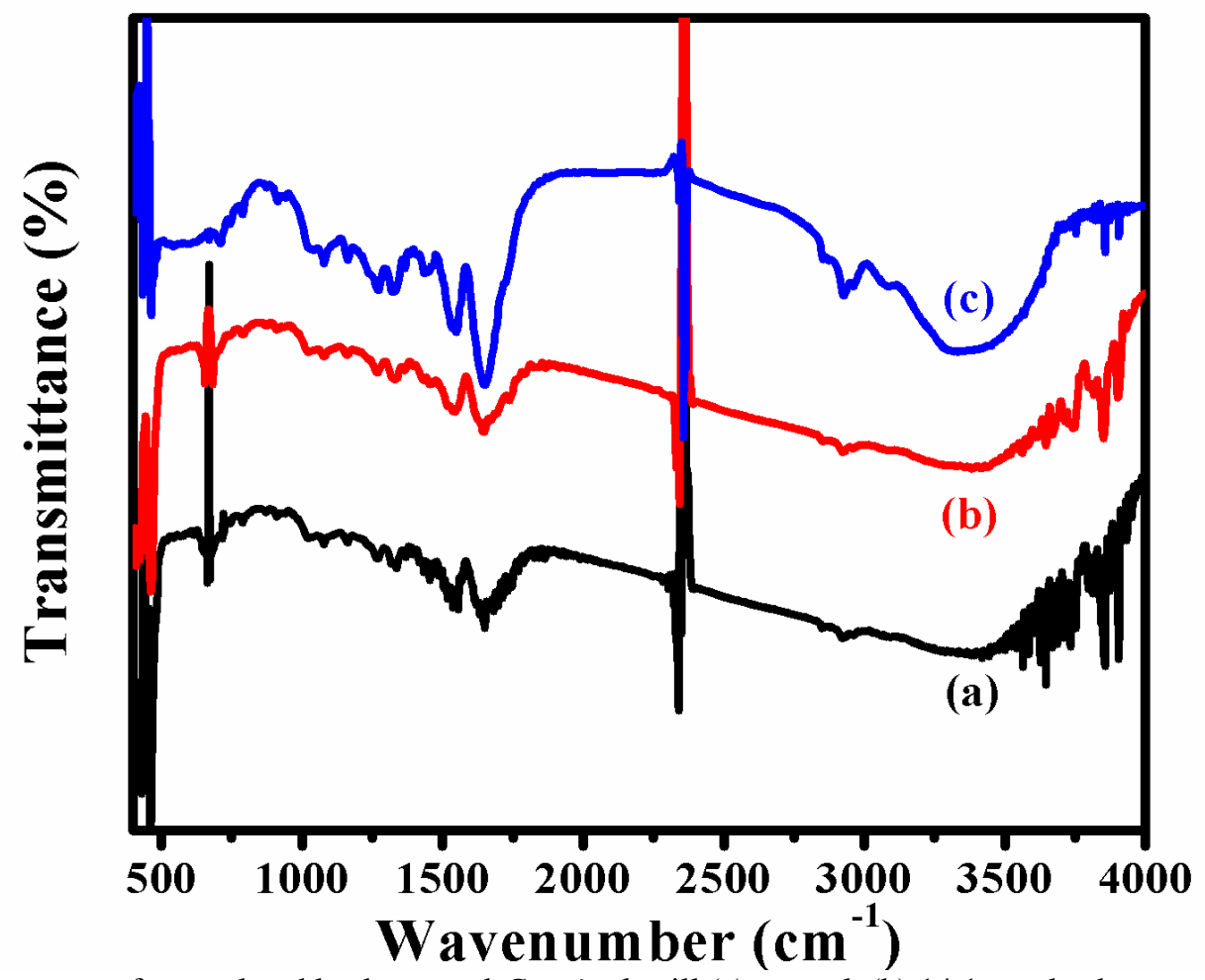

Fig.1:-FTIR spectra of control and lead exposed $C$-mrigala gill (a) control, (b) $14.1 \mathrm{ppm}$ lead exposure, (c) $28.2 \mathrm{ppm}$ lead exposure 
Field emission scanning electron microscopic study (FESEM):-

Scanning Electron Microscopy of gill from $\mathrm{Pb}$ treated C. mrigala in the present study revealed impairment in lamellae and also shown abnormalities and changes in architectural pattern of gill units. The surface morphological study has been carried out for gill of control and lead exposed fish. Gills are sensitive organs for studying the effect of heavy metals. Various histological alterations observed by light microscopy at low resolutions are confirmed by SEM images. The Fig. 2 (A1 and A2) shows a homogeneous intact arrangement of lamellar cells in control samples. A normal fish shows gill arches which are supported by numerous gill filaments arranged in two rows called hemi branches. At the bases of lamellae limited chloride and mucous cells are seen. The gill of control fish appeared to be normal with the uniform branching of thin, slender secondary lamellae attached to either side of primary gill lamellae. The gill filaments show micro ridges on the epithelial surface. The secondary gill lamellae are placed successively at more or less equidistance. The Fig. 2 (B1 and B2) shows rough and scattered arrangement of lamellar cells in gills of fish exposed to 14.1 concentration of lead acetate. The abundance of cell is observed to be decreased after lead exposure. Loss of secondary gill lamellae and its integrity with the primary gill lamellae is prominent. Further decrease and morphological alteration like disintegration of lamellar epithelium, fusion of secondary gill lamellae and its disintegration are seen in gills of fish exposed to and 28.2ppm lead acetate concentration. These alterations are seen in Fig.2 (C1 and C2). FESEM study reveals significant metal exposure induced alterations in gill. Alterations like reduced lamellar cells and surface structure transformations are directly proportional to intensity of toxicant. The transformation may lead to functional alterations and disturb the fundamental function of gill (Jezierska et al., 2009)The results indicated distinct degeneration as well as impairment and disturbance in gill lamellae structure due to lead toxicity which further changes gill filament properties. Gill is an organ associated with vital functions like gas exchange and waste removal. Metal induced altered oxygen absorption and ormoregulation in fish results in histological alterations in gill (Karl-johan Lehtinen, 1983).Light microscopic studies on histopathology of various fish gills after exposure to toxicants has been reported by many researchers (Chavan and Muley, 2014; Gupta and Kumar, 2006). SEM study of fish gill has been reported by Aldogachi et al., (2015)(Aldoghachi et al., 2015) indicating impact of lead on gill filaments like necrosis, fusion and proliferation of epithelial cells. Muthukumarvel et al., (Muthukumaravel et al., 2013) studied the severe toxic effects of cadmium on gill of Labeo rohita by SEM. The present study corresponds with these studies and provides better understanding of lead toxicity to fish gill. The result demonstrates that lead causes structural and functional impairment in fish gill. 

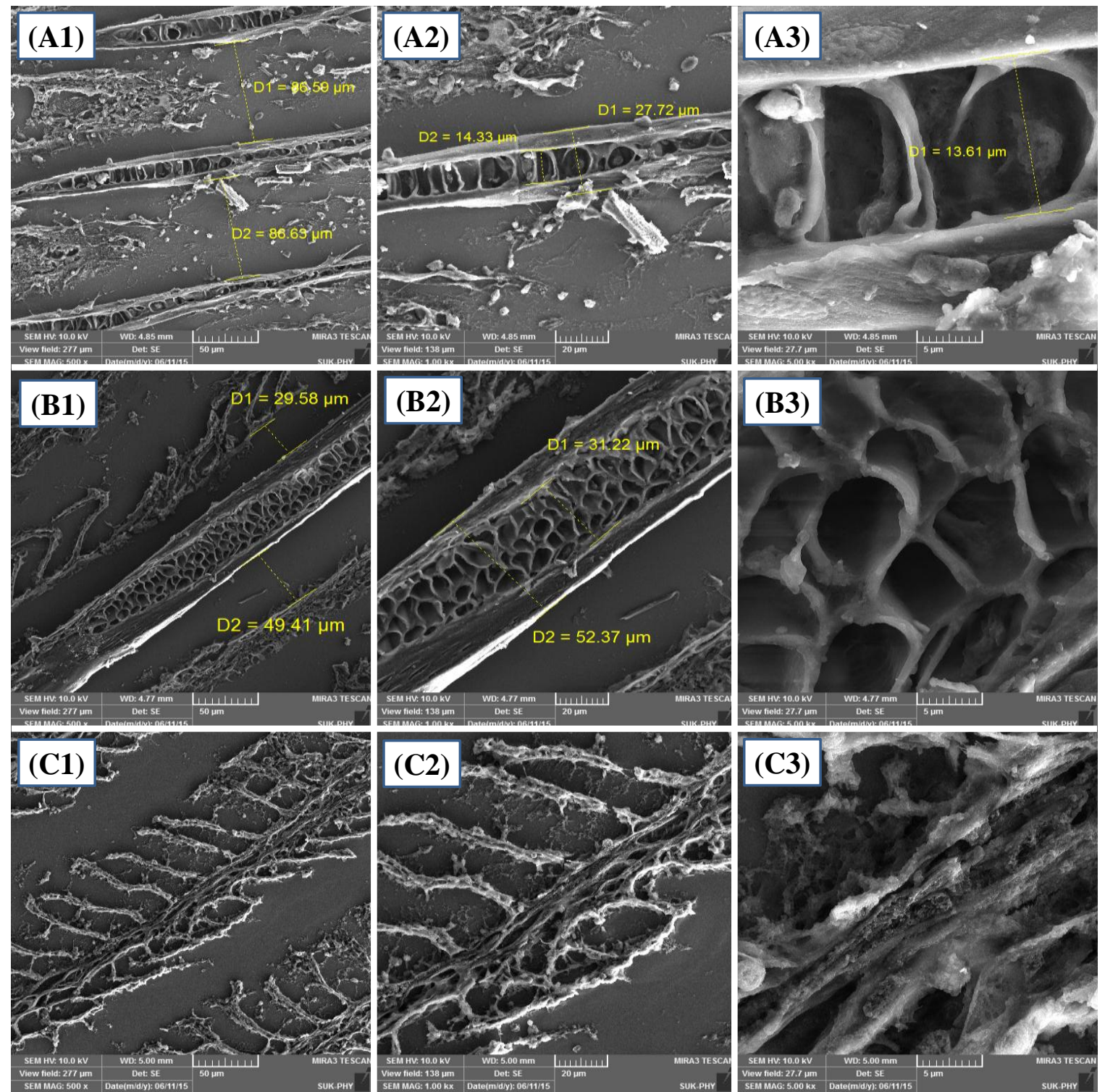

Fig. 2:- FE-SEM images of control and lead exposed $C$-mrigala gill (A1) Control $\mathrm{X}=500 \mathrm{x}$, (A2) Control $\mathrm{X}=1 \mathrm{kx}$, (A3) Control $X=5 \mathrm{kx}$, (B1) $14.1 \mathrm{ppm}$ lead acetate $X=500 \mathrm{x}$, (B2) $14.1 \mathrm{ppm}$ lead acetate $X=1 \mathrm{kx}$, (B3) $14.1 \mathrm{ppm}$ lead acetate $X=5 \mathrm{kx},(\mathrm{C} 1) 28.2 \mathrm{ppm}$ lead acetate $\mathrm{X}=500 \mathrm{x},(\mathrm{C} 2) 28.2 \mathrm{ppm}$ lead acetate $\mathrm{X}=1 \mathrm{kx}$, (C3) $28.2 \mathrm{ppm}$ lead acetate $\mathrm{X}=5 \mathrm{kx}$.

\section{Energy Dispersive X-ray Spectroscopic Study (EDS):-}

Fig. 3 shows the EDS spectra of control and lead exposed $C$-mrigala gill. The EDX analysis has been carried out to reveal the effect of lead on carbon oxygen percentage of gill tissue. The observed weight and atomic percentage of carbon, oxygen and nitrogen have been mentioned in Fig .3. For the control sample nitrogen has not been observed. But in lead exposed samples nitrogen is detected and this result is consistent with FTIR results. The observed weight and atomic percentage of carbon is 72.37 and 77.72, respectively. Similarly, the weight and atomic percentage of oxygen is 27.63 and 22.28, respectively. This is shown in Fig. 3(a). The Fig.3 (b) shows EDS spectrum for 14.1 ppm lead expose samples. After the lead exposed at $14.1 \mathrm{ppm}$ along with nitrogen and oxygen, carbon has been detected in EDS spectrum. The weight and atomic percentage of carbon is 55 and 60.61, respectively. The weight and atomic percentage of oxygen is 26.62 and 22.02, respectively. Also, the weight and atomic percentage of nitrogen is 18.38 and 17.37, respectively. The observed weight and atomic percentage of carbon oxygen and nitrogen for lead exposed at $28.2 \mathrm{ppm}$ have been mentioned in Fig.3 (c). The weight and atomic percentage of carbon is 56.35 and 61.78 , respectively. The weight and atomic percentage of oxygen is 24.11 and 19.78, respectively. The weight and atomic 
percentage of nitrogen is 19.55 and 18.38, respectively. The change in weight and atomic percentage of carbon, oxygen and detection of nitrogen is due to lead exposure.

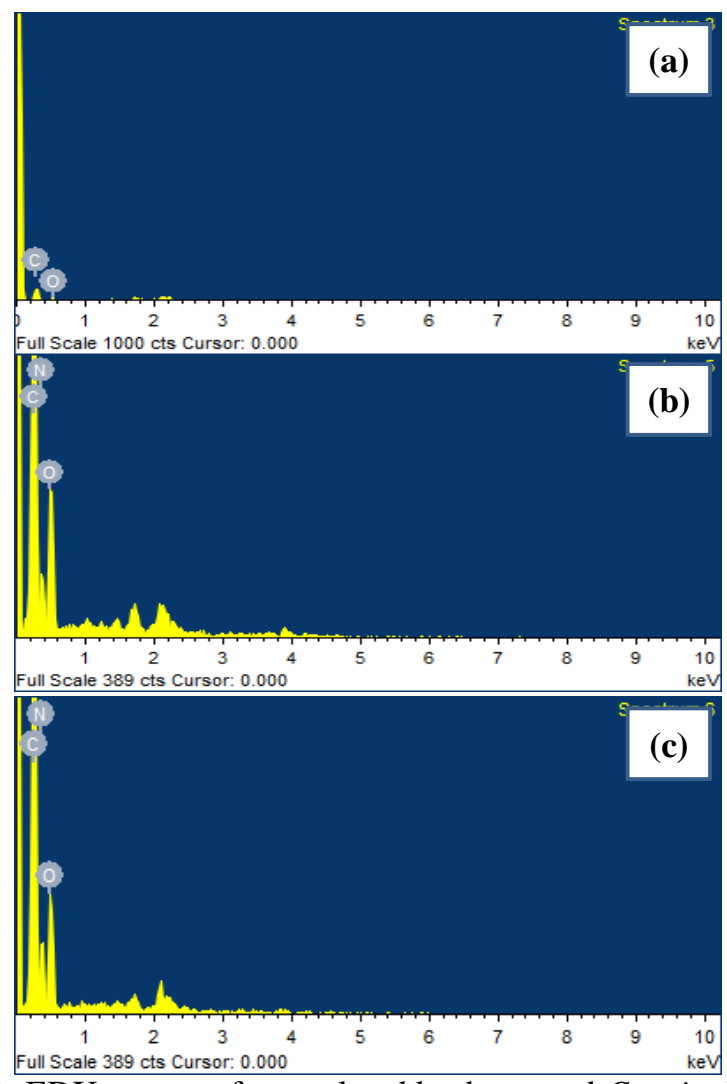

$\begin{array}{lll}\text { Element } & \text { Weight\% } & \text { Atomic\% } \\ \text { C K } & 72.37 & 77.72 \\ \text { O K } & 27.63 & 22.28\end{array}$

Fig. 3:-EDX spectra of control and lead exposed C-mrigala gill (a) control, (b) $14.1 \mathrm{ppm}$ lead acetate, (c) $28.2 \mathrm{ppm}$ lead acetate.

\section{Optical absorbance:-}

Optical behavior of Gill of C. mrigala has been studied using UV-Vis spectrophotometer. An accessible evaluation of absorption of photons, leading to an excitation of an electron from the valence band to the conduction band is done by UV-Vis spectrophotometer (Gaurav M. Lohar et al., 2015; Lohar et al., 2015, 2015). The optical absorbance has been studied with dissolving of prepared gill powder in methanol for control and lead exposed sample. The optical absorbance has been observed near at $430 \mathrm{~nm}$ for control sample and this is shown in Fig.4. After the lead exposure at $14.1 \mathrm{ppm}$ optical absorbance peak observed at $426 \mathrm{~nm}$ and lead exposed at $28.2 \mathrm{ppm}$ the absorbance peak observed at $410 \mathrm{~nm}$. After the lead exposure absorbance has been blue shifted from its original absorbance. This is the impact of lead exposure. After the lead exposure, change has been observed in absorbance. The change in absorbance is also indicating the effect of lead exposure. For the control sample, the absorbance has been observed to be decreased at $303 \mathrm{~nm}$ to $285 \mathrm{~nm}$. After the $285 \mathrm{~nm}$ the absorbance has been again increased upto $265 \mathrm{~nm}$. For the lead exposed at $14.1 \mathrm{ppm}$, the absorbance has been decreased at $299 \mathrm{~nm}$ to $284 \mathrm{~nm}$ and absorbance has been again increase from 285 to $269 \mathrm{~nm}$. Similarly, absorbance has been observed to be decreased at $312 \mathrm{~nm}$ to $285 \mathrm{~nm}$ for lead exposed sample at 28.2ppm. Again increase in absorbance has been observed 285 to $265 \mathrm{~nm}$. The absorbance has been observed in UV region also. This indicate that, this gill of $C$. mrigala have been active in UV region also. 


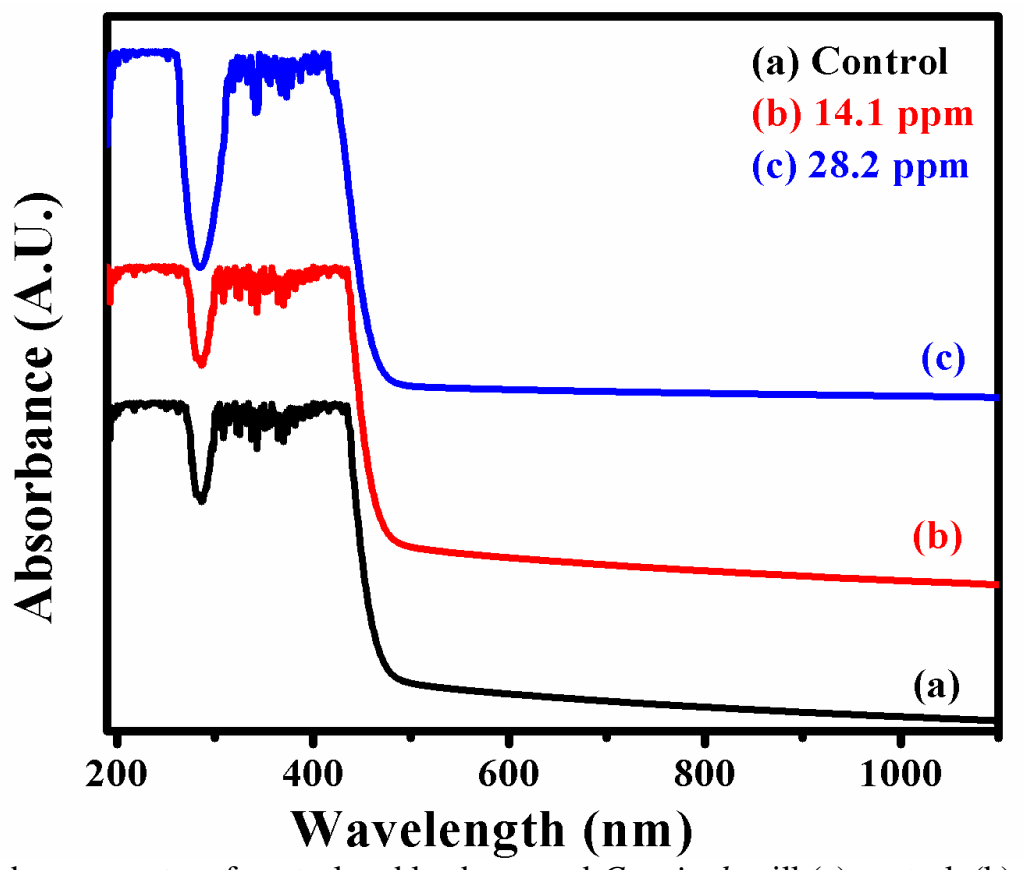

Fig. 4:-Optical absorbance spectra of control and lead exposed $C$-mrigala gill (a) control, (b) 14.1 ppm lead acetate, (c) 28.2 ppm lead acetate.

Fig. 5:-Photoluminescence spectra of control and mercury exposed $C$-mrigala gill (a) control, (b) $14.1 \mathrm{ppm}$ lead acetate, (c) 28.2 ppm lead acetate.

\section{Conclusion:-}

The complex biochemical composition of fish gill and its alterations due to lead toxicity are revealed by IR study. Structural changes in gill histology after lead toxicity are better understood by FESEM study. The ultra-structural and biochemical changes can be used as biomarker for assessing heavy metal pollution. The present study provides better understanding on significant disturbance and impairment in gill architecture and its functional failure. These toxicity studies can be used to assess the status of fresh water reservoirs and their productivity.

\section{References:-}

1. Abdel-Baki, Dkhil, M.A., -Quraishy, A., 2011. Bioaccumulation of some heavy metals in tilapia fish relevant to their concentration in water and sediment of Wadi Hanifah, Saudi Arabia. African J. Biotechnol. 10, 25412547. doi:10.5897/AJB10.1772

2. Agah, H., Leermakers, M., Gao, Y., Fatemi, S.M.R., Katal, M.M., Baeyens, W., Elskens, M., 2010. Mercury accumulation in fish species from the Persian Gulf and in human hair from fishermen. Environ. Monit. Assess. 169, 203-216. doi:10.1007/s10661-009-1162-8

3. Al-Balawi, H.F.A., Al-Akel, A.S., Al-Misned, F., Suliman, E.A.M., Al-Ghanim, K.A., Mahboob, S., Ahmad, Z., 2013. Effects of sub-lethal exposure of lead acetate on histopathology of gills, liver, kidney and muscle and its accumulation in these organs of clarias gariepinus. Brazilian Arch. Biol. Technol. 56, $293-302$. doi:10.1590/S1516-89132013000200015

4. Aldoghachi, M.A., Azirun, M.S., Yusoff, I., Ashraf, M.A., 2015. Ultrastructural effects on gill tissues induced in red tilapia Oreochromis sp. by a waterborne lead exposure. Saudi J. Biol. Sci. $\quad$-. doi:http://dx.doi.org/10.1016/j.sjbs.2015.08.004

5. Burger, J., Gochfeld, M., 2005. Heavy metals in commercial fish in New Jersey. Environ. Res. 99, $403-412$. doi:10.1016/j.envres.2005.02.001

6. Cakmak, G., Togan, I., Severcan, F., 2006. 17??-Estradiol induced compositional, structural and functional changes in rainbow trout liver, revealed by FT-IR spectroscopy: A comparative study with nonylphenol. Aquat. Toxicol. 77, 53-63. doi:10.1016/j.aquatox.2005.10.015

7. Chavan, V.R., Muley, D. V, 2014. Original Research Article Effect of heavy metals on liver and gill of fish Cirrhinus mrigala. Int. J. Curr. Microbiol. Appl. Sci. 3, 277-288. 
8. David, M., Kartheek, R.M., 2015. Histopathological alterations in spleen of freshwater fish Cyprinus carpio exposed to sublethal concentration of sodium cyanide 5, 1-5. doi:10.1007/s11356-015-5286-9

9. Gupta, A.K., Kumar, A., 2006. Histopathological lesions in the selected tissues of Cirrhinus mrigala (Ham.) fingerlings exposed to a sublethal concentration of mercury. J. Environ. Biol. 27, 235-239.

10. Jezierska, Barbara; Sarnowski, Pioter; Małgorzata, Witeska; Katarzyna, Ł., 2009. Disturbances of Early Development of Fish Caused By Heavy Metals (a Review). Electron. J. Ichthyol. 2, 76 - 96.

11. Karl-johan Lehtinen, G.K., 1983. X-ray-microanalysis-in-the-scanning-electron-microscope-on-fish-gillsaffected-by-acidic-heavy-metal-containing-industrial-effluents_1983_Aquatic-Toxi.pdf.

12. Krafft, C., Sobottka, S.B., Schackert, G., Salzer, R., 2004. Analysis of human brain tissue, brain tumors and tumor cells by infrared spectroscopic mapping. Analyst 129, 921-925. doi:10.1039/b408934k

13. Lohar, G.M., Dhaygude, H.D., Patil, R.A., Ma, Y.-R., Fulari, V.J., 2015. Studies of properties of Fe2+ doped ZnSe nano-needles for photoelectrochemical cell application. J Mater Sci Mater Electron 26, 8904-8914.

14. Lohar, G.M., Jadhav, S.T., Dhaygude, H.D., Takale, M. V, Patil, R.A., Ma, Y.R., Rath, M.C., Fulari, V.J., 2015. Studies of properties of $\mathrm{Fe} 3 \mathrm{p}$ doped $\mathrm{ZnSe}$ nanoparticles and hollow spheres for photoelectrochemical cell application. J. Alloys Compd. 653, 22-31. doi:10.1016/j.jallcom.2015.08.208

15. Lohar, G.M., Jadhav, S.T., Takale, M.V., Patil, R.A., Ma, Y.R., Rath, M.C., Fulari, V.J., 2015. Photoelectrochemical cell studies of $\mathrm{Fe} 2+$ doped $\mathrm{ZnSe}$ nanorods using the potentiostatic mode of electrodeposition. J. Colloid Interface Sci. 458, 136-146. doi:10.1016/j.jcis.2015.07.046

16. Messner, W., 2016. The impact of an aircraft's service environment on perceptions of in-flight food quality. J. Air Transp. Manag. 53, 123-130. doi:10.1016/j.jairtraman.2016.02.010

17. Muthukumaravel, K., Prithiviraj, N., Ramesh, M., Sekar, V., Salahueen, B.S.M., 2013. Light and Scanning Electron Microscopic Evaluation and Effects of Cadmium on the Gills of the Freshwater Fish , Labeo rohita 4, 999-1006.

18. Oliveira, M., Pacheco, M., Santos, M.A., 2008. Organ specific antioxidant responses in golden grey mullet (Liza aurata) following a short-term exposure to phenanthrene. Sci. Total Environ. 396, 70-78. doi:10.1016/j.scitotenv.2008.02.012

19. Rurangwa, E., Roelants, I., Huyskens, G., Ebrahimi, M., Kime, D.E., Ollevier, F., 1998. The minimum effective spermatozoa : egg ratio for artificial insemination and the effects of mercury on sperm motility and fertilization ability in Clarias gariepinus. J. Fish Biol. 53, 402-413. doi:10.1111/j.1095-8649.1998.tb00989.x

20. Toyran, N., Turan, B., Severcan, F., 2007. Selenium alters the lipid content and protein profile of rat heart: An FTIR microspectroscopic study. Arch. Biochem. Biophys. 458, 184-193. doi:10.1016/j.abb.2006.12.012

21. Vosylienè, M., Jankaite, a, 2006. Effect of heavy metal model mixture on rainbow trout biological parameters. Ekologija 12-17. 